\title{
Role of social capital in disaster risk management: a theoretical perspective in special reference to Odisha, India
}

\author{
J. K. Behera ${ }^{1}$ (iD
}

Received: 22 January 2021 / Revised: 8 June 2021 / Accepted: 9 October 2021 / Published online: 28 October 2021

(C) Islamic Azad University (IAU) 2021

\begin{abstract}
Social capital being the network of relationship plays a significant role in managing risk and crisis situation saving human lives from an adverse effect and impact of disasters. The authors and scholars across many countries through their disaster studies show that social capital with the form of bonding, bridging and linking rescued the victims of disasters, evacuated the most vulnerable people to safer places, provided food and drinking water and other basic amenities to the victims of disasters, provided homes to the homeless and solaced to those who were psychologically depressed. However, the literature review further specified that while bonding and bridging social capital extended support to the victims of disasters in abundance, the linking social capital on the other hand supported only to those who are in close contact with the persons and institutions in power and authority. Review of literature is done purely through qualitative research methodology which has had read 86 relevant articles published within the last 10- to 12-year period of time. This review paper both contributes to the social capital literature and helps those responsible for planning and policy framework to effectively manage future disasters and safeguard lives and properties and enhance capacities of the most vulnerable people to absorb shocks and stress successfully.
\end{abstract}

Keywords Trust and solidarity · Social network · Risk and crisis management - Social capital · Empirical evidence Natural disasters $\cdot$ Collective action and cooperation $\cdot$ Social values

\section{Introduction}

Many natural calamities across the world occur every year affecting millions of people today (Montz et al. 2017). In the year 2016, 342 natural disasters hit globally where 564 million people worldwide were affected severely (Guha-Sapir et al. 2016). [p2] Therefore people in post-disaster situation suffer immensely due to damage of resources, infrastructure and livelihood. (ibid).

Disasters once considered as 'natural' and thus acts of God. The notions of people's capacities and expertise were insufficient to reduce the occurrence of disasters. Since the time immemorial, many countries across the world

Editorial responsibility: Xu Han.

\section{J. K. Behera}

190506172003@cutm.ac.in

https://cutm.ac.in

1 Department of Management, Centurion University of Technology and Management, Ramchandrapur, Khurda Road, Odisha state, Jatni, Bhubaneswar, India witnessed multiple disasters and the adverse effect and impact people encountered. The world leaders and development planners headed by United Nations realized the pivotal importance of pre-disaster activities such as prevention, mitigation, preparedness and early warning so as to minimize the deadly impact of disasters (O'Keefe et al. 1976). Since the year 1970s, many researchers and scholars in and through their relevant study findings perceived that the negative impact of disasters on the lives, livelihood and infrastructures is largely due to people's vulnerabilities and lack of pertinent capacities (ibid). Hence, the paradigm has shifted from disaster response to disaster risk management (DRM).

United Nations organized the World Conference on Disaster Risk Reduction and developed Hyogo Framework for Action from 2005 to 2015 that aimed to develop and strengthen the capacities of people in all aspects of life in order to reduce the impact of disasters (UN/ISDR 2005). Subsequently, the second International Conference on Sendai Framework for Disaster Risk Reduction held in Sendai, Japan, on March 18, 2015, and developed plan of action from 2015 to 2030 . The aim of this conference is to achieve 
substantial reduction of disaster risk and losses in lives, livelihood, physical, social and environmental assets of individuals, families and communities (UNSFDRR, 2015). The focus turned to reducing vulnerability instead of strengthening infrastructure (ibid).

Many scholars explore that human, financial, physical, natural and social capitals are vast and very important resources to address disaster risk management. Among all these resources, the review paper envisages social capital as one of the vital ingredients among all other capitals that effectively facilitate reducing the effect and impact of disasters to a great extent (Koh 2008). As observed and witnessed the response measures aftermath of the earthquake 1995 in Kobe that when the local government had limited capacity to deal with an enormous crisis, people, volunteers, relatives and friends from the localities spontaneously responded to the victims and saved their lives, cleared debris and provided food to the disaster affected people (Nakagawa and Shaw 2004).

According to Dynes (2006), disaster affects all four capitals such as economic, physical, natural, human and social capital. However, among all these capitals, social capital comparably least damaged by disaster moreover the capacities and engagement of social capital in risk and crisis management increased during disaster. Nevertheless, Social capital stands as one of the vital resources for the individuals, groups and communities to prepare for upcoming disasters and hazards respond effectively to emergencies and recover people from the deadly impact of disasters (Aldrich 2012a, 2012b), 2012c; Dynes 2002; Granovetter 1983b; Norris et al. 2002).

Social capital intervenes in various fields of relevance as and when required. Health is one of such important sector where social capital plays pivotal role in preventing and controlling of diseases and virus effectively. For example, when the epidemics known as Severe Acute Respiratory Syndrome (SARS) spread in 2003, the outbreak of Ebola Virus Disease in the year 2014 and the widespread epidemic of Zika fever caused by Zika virus in the year 2015, social capital played crucial role in sensitizing people on preventive measures and above all made people to be at peace and calm (Blair et al. 2017; Wilkinson and Fairhead 2017).

The Corona Virus Disease-19 has threatened the world communities on the safety and security of human life. The COVID-19 has claimed millions of people within a short period of time, and millions of people of this century still suffer with the deadliest killing effect of the virus today. Different countries and communities have adopted varied steps to prevent and control the deadliest disease and so some countries and regions have better effect on preventing the virus and others are not. According to the findings of some scholars, social capital in some regions has played a significant role in prevention and controlling measures in and through practicing COVID-19 protocol and guideline and sensitized others to follow strictly to keep themselves safe and allow others to be at safe (Bai et al. 2020; Barrios et al. 2020; Borgonovi and Andrieu 2020; Fraser and Aldrich 2020).

The disaster risk management of individuals and communities depends on effective risk and crisis management, i.e. preparedness, early warning, response and recovery measures (Dynes 2006; FEMA 2010). Social capital as resource helps people and community in pre, during and post-disaster situation for better disaster risk management. Prior to a disaster, social capital facilitates series of activities such as vulnerability assessment, capacity assessment, stockpiling, shelter preparation, repairing of partially damaged houses, early warning, preposition of rescue equipment, first aid and other lifesaving exercises (ibid).

During a disaster, social capital helps the communities to make better evacuation decisions, search and rescue and provide immediate and long-term relief and recovery measures. Social capital has also crucial role to play providing food to the hungry, initiate debris removal, make provision of shelters for homeless, child care, financial aid, initiate immediate emotional and psychological support (Aldrich and Meyer 2015; Dynes 2005; Norris et al. 2002; Sanyal and Routray 2016). Moreover, linkages between social capital and disaster risk management can bind community together and that ultimately enhance disaster resilience of the people (Berkes and Ross 2013).

Social capital sometime get decreased with values by the impact of disasters as individual members, families and communities network get disconnected and naturally the built network get disassociated and the network ties breaks (Kaniasty and Norris 1993; Ritchie and Gill 2007; Varda et al. 2009). Moreover, disasters can become a cause of increasing social vulnerabilities by damaging social ties and networks of resource as a result of which the capacity of absorbing shocks may get decline further (Domínguez and Watkins 2003; Tobin-Gurley et al. 2010; Aldrich 2012a, 2012b), 2012c). The objective of this review paper meant to highlight what difference social capital can make for and with the disaster affected communities in pre-, during and post-disaster situation and how it could be best useful in disaster risk management reviewing the empirical evidences from many literature.

The literature review has been carried out in special reference to the Puri District, Odisha State, India, known as one of the most disasters-prone regions in India within the period from October 2020 to April 2021, and the deeper level field survey is in process. The researcher intended to make deeper research on the same subject as part of $\mathrm{PhD}$ research work. The prime objective of the literature review was to discover what role and contribution social capital made in pre-, during and post-disaster situation and saved the most vulnerable 
and affected people from the adverse impact of disasters in many countries and assisted them in short-term and longterm response and recovery programs.

\section{Methodology}

Review of literature is done purely through qualitative research methodology. The researcher tries to gather relevance data and findings on the role of social capital in disaster risk management and through secondary source of literature review from 86 relevant articles within the last 10- to 12-year period of time.

\section{Theoretical framework}

\section{Social capital}

Hanifan (1916) was the first social scientist who promoted social capital as goodwill, fellowship, mutual sympathy and social intercourse among a group of individuals and families who make up a social unit. Social capital as the theoretical concept further explored and publicized in the works of Bourdieu (1986) Coleman (1988, 1990), Woolcock (1998) and Putnam $(1994,1995)$. Social Capital is defined as exchange of information, trust, norms and values between and among the individuals, groups, families and communities and with an existing network, while physical capital is fully tangible and the social capital merely exists invisibly in the form of relationship between and among individuals (Coleman, 1988).

A series of definitions on the concept of social capital are available in the literature. Broadly speaking, social capital is an ability of people to work together for common purposes in groups and organizations (Fukuyama 1995) with the set of informal values or norms that motivates cooperation between and among groups. (ibid) The social scientists (Bourdieu 1986; Coleman 1988; Putnam 1993, 1995; Lin et al. 2008) have defined social capital that refers to the networks which connect individuals, families, groups with each other either through weak or strong ties. Woolcock and Szreter showed a path in 2004 in which social capital can be categorized into horizontal and vertical networks such as bonding, bridging and linking social capital which can be widely used to save lives in emergencies (Adler \& Kwon, 2014; Szreter and Woolcock 2004). Bonding social capital in the first hand is explained as the close horizontal relations between and among immediate families, friends, business associates or individual members of the community sharing the same demographic characteristics and socio-economic status homogenous to each other. Bridging social capital is further explained stating a bit different from bonding as connecting individuals, groups and families more heterogeneous to each other although with the similar socio-economic and political status, whereas linking social capital which is the vertical connection between people of different strata of power and position and the individuals and communities is able to develop network and benefit from linking social capital (ibid).

On the one hand, bonding social capital is essential for strengthening social unity among individuals, families, groups and communities, bridging social capital speaks for solidarity, respect and understanding in wider society, and linking social capital is a resource or capacity of the people and communities to mobilize various resources to their essential needs for recovery and reconstruction purposes (Poortinga 2012). Therefore, bonding, bridging and linking social capital offer a sense of belongingness, unity, cooperation and mutual support among people, families and groups to get access to needful resources and services as and when require (UN/ISDR \& UN/OCHA 2008).

Social capital is a relationship built between and among individuals, families and community as resource to work together for common purposes and get benefit (Huvila et al. 2014). Sharing of information, trust and cooperation between and among the individuals, families, groups and social networks is also considered as social capital. (Bourdieu 1986; Woolcock 1998). Similarly, for Putnam $(1995,2000)$ social capital is defined as the networks, connection and groups with shared values and understanding in the society that enable individuals and groups to trust each other and work for positive result on the wake of disasters (Keeley, 2007). Social capital is created with filial relationship, shared norms, values and understanding that promotes support and cooperation between and among individuals, families, groups and other networks (OECD 2001; Perry 1979). For example, Siegler (2014) argues that social capital brings about networks, connections and human values that promote benefits due to tolerance, solidarity and or trust.

\section{Social capital and disaster risk management}

Social relations, trust and solidarity, collective action and cooperation are the true resources and ingredients for the individuals, groups and communities to effectively manage risk and crisis situation (Aldrich 2012a, 2012b), 2012c; Aldrich \& Meyer 2015; Pfefferbaum et al., 2017). In addition "how involvement and participation in groups can have positive consequences for the individual and the community" (Aldrich \& Meyer, 2015, p. 256).

The thrust of successful disaster management as stated by UNDP lies in: "cooperation, coordination, collective action, and information sharing" (UNDP, 2016b, p. 39). Such kind of positive relations, understanding and reciprocal action 
embedded in social capital keeps the community, groups and individual together. William Robinson opines "social capital is the "oil that reduces friction in communities ... [and is] an essential condition of social cohesion' which is a critical component of DRR and resilience". "Social capital creates bonds between individuals that incentivises them to cooperate and encourages them to generate new ideas, utilise invisible resources, and grow as a community" (Sanyal and Routray, 2016). "These bonds allow members to bring shared problems to the attention of the community, facilitate discussion forums to find solutions, and act collectively to mobilise political will for the reduction of disaster risk" (Mayunga, 2007, p.7). Disaster risk management aims to carry out activities by communities in a systematic manner with a four pillars in mind including relief/response, recovery, mitigation, preparedness (Guha-Sapir et al. 2011).

\section{Empirical view on the Role and function of social capital in disasters}

\section{Empirical evidence of social capital in disaster response}

In the year 1995 Kobe, Japan witnessed one of the deadliest earthquakes. Hundreds and thousands of people killed; hundreds of victims were stranded under debris and inside the damaged houses. The first-hand responders who could save lives and rescued the stranded ones were their own relatives, neighbours, passersby and friends (Aldrich, 2012a, 2012b), 2012c).

Nakagawa and Shaw (2004) claimed that the communities with increased network of relationship exhibited effective response and recovery measures aftermath of the earthquake in India and Japan. Dynes (2005) with his research findings affirmed that social ties, social network, shared values and reciprocity are the root for bouncing back from the adverse impact of disasters, as it extends support services like sharing of pertinent information and lifesaving resources at the time of critical period. Such kind of benevolent acts is rendered by Individuals, groups, family members, relatives and friends (Poteyeva et al. (2007)

Thailand the capital city of Bankok faced the worst flood in the year 2011 in its recorded history. $\$ 45$ billion cost of properties, assets and infrastructures got damaged as about $90 \%$ of some areas were submerged with flood water. The severity and magnitude of disaster were so big that 9 million family members were unable to move to the safer places and managed to survive with the available food stock, water and other necessities preserved in advance. On the other hand, the district of Sai Noi in the northwest suburbs of the city was different from the other affected areas. The people of Sai Noi worked together and fought the raging flood water.
"People of Sai Noi with no training and skills could build barriers and fill sand bags in the risky river embankment and monitored flood levels, delivered food and drinking water to all the families in need, evacuated the residents trapped in their homes, provided medical services to the sick and injured and the volunteers were on constant watch on looters" (Roasa 2013: 1).

According to Allen (2013), the past disasters like bushfires, cyclones, storms and floods impacted people in Australia very badly. At this critical juncture, the benevolent Australians spontaneously helped those who were affected by the disasters. The neighbours, relatives and the people in the same locality came together and extended basic support and services before the government could reach and rescue the victims [ibid]. Evidence is also found that bonding social capital extended all necessary food and nonfood support to the flood affected people in Myanmar and Taiwan in the year 2012 before government functionaries could reach them on time (James, 2012).

The post-cyclone Yasi of 2011 in Australia gave opportunity of activating social capital of bonding and bridging by dint of which local community, volunteers, groups and relatives helped those in need with labour and machinery (Allen, 2013). Early warning and dissemination of pertinent information regarding relief received by the affected people are generally from relatives and friends. Although government is a prime support providing institution, social capital played a pivotal role in proving support to the people affected by the disaster (Zhao et al. 2013).

During and after the Oakland California firestorm in 1991, people both young and old fleeing to rescue themselves were picked up by passing cars and motorbikes. As part of bonding social capital, relatives and neighbour went house-to-house and rescued the victims from a flame of fire (Oliver-Smith, 1999).

\section{Empirical evidence of social capital in disaster recovery}

According to Smith and Wenger, disaster recovery is "the differential process of restoring, rebuilding, and reshaping, the physical, social, economic, and natural environment through pre-event planning and post event actions" (p 237). The prime purposes of initiating activities during recovery phase are to restore the victims and affected families back to the normal condition or better than what was before (Cardona, 2004), Kates et al. 1977). As like response phase, several authors have highlighted strong role that social capital played during recovery phase (Nakagawa and Shaw 2004), (Edgington, 2010), Patterson et al. (2010). Bonding, bridging and linking social capital also have played very important role in contributing positively to the overall recovery of a disaster affected community (Sobel, 2002). For example, 
although in Philippines the disaster network called Disaster Response Network (CDRN) is active in all phases risk and crisis management and yet during recovery phase the network engaged in repairing and rebuilding homes, and implemented the distribution of seed, livestock and tools (Delica-Willson, and Wilson, 2004).

Normally community organizations have no core capacity for disaster risk management, and yet instances indicate that many of the community organizations play extra role and functions in pre-, during and post-disaster situation providing necessary support to the group members and individuals in the communities. For example, aftermath of the Indian Ocean tsunami in 2004, non-government organizations (NGOs) played lifesaving role in distributing relief both food and non-food items to the individuals, families and groups mostly in need as the government relief materials and resources were unable to reach to these communities (Kumaran et al. 2011). The community leaders and members having strong and positive link with the local non-government organization could reach those most in need. Having successfully fighting with the 2004 tsunami in India, the South Indian Federation of Fishermen Societies (SIFFS), and Society for Nutrition, Education and Health Action (SNEHA) built local networks to advocate for community needs in coming days and in future (IFRCRCS. 2005). These networks and organizations with one voice advocated before the government to shape government policies concerned with the provision of quality temporary housing and the reconstruction of permanent residences.

\section{Empirical evidence of social capital in prevention and mitigation}

Disaster prevention and mitigation are on-going processes known as risk reduction measures normally carried out in pre-disaster situation so as to lessen or prevent exposure to loss of life and properties (Mitchell et al. 2010). On the one hand, preventive measure concerned with avoiding exposure to hazard that may adversely impact people, and on the other hand, mitigation measure is to minimize the impact of an event may occur in future (Smith and Petley 2009).

Treatment, prevention and controlling the COVID-19 are not only the duties and responsibilities of Government machineries but everyone's responsibilities to follow COVID-19 guideline to be at safe and allow others also to be safe. The present-day scholars have critically made studies on COVID-19 and indicated the evidence that social capital has effectively carried out preventive measures, maintained social distances and exposed themselves to the outer world only when essentially required. This was one of the reasons why the trend of rising the cases of infection in some areas was lower than other areas (e.g. Bai et al. 2020; Barrios et al. 2020; Bartscher et al. 2020; Borgonovi and Andrieu 2020).
Similarly, some regions in Japan as per the observation of Fraser and Aldrich (2020) that people were more prone to infection of coronavirus due to physically and socially closer to their relatives, neighbours and friends. But later on when people with collective action and cooperation followed COVID guideline strictly that made the drastic reduction in infection rate.

Some scholars and researchers in Italy observed closely and reported that due to strong COVID guideline followed by the families, relatives and neighbours the high rise of infection lowered down (Bartscher et al., 2020). Another research was carried out in the same region of Italy taking a few sample of professionals and officers and their mode of operation. The study report shows that the employers and employees followed the strict COVID-19 guideline and strictly followed social distance, sanitized hands, wear mask and other preventive measures whenever they were working in the offices (Kokubun 2020).

As observed by Dynes, strong social networks and groups become source of inspiration and motivation for others to take part in preventive measures. Similarly, the USA (Committee on Disaster Research in Social Sciences, 2006) identified that community with high levels of social capital is more likely to engage in mitigation strategies as core business. For example, in Antique, Philippines, a country with high involvement in local associations, community members come together to construct dams for flood control (Bankoff, (2007). These communities show strong understanding of existing capacities, which results in realistic and achievable mitigation strategies that harness the community's specific strengths.

In Santa Cruz, California, Neighbourhood Survival Networks (NSN) implemented series of risk and crisis management activities in pre-, during and post-disaster situation, especially aiding the minority and vulnerable populations in the aftermath of the 1989 Loma Prieta earthquake (Committee on Disaster Research in the Social Sciences and National Research Council. 2006).

\section{Empirical evidence of social capital in preparedness}

Disaster preparedness is the set of activities undertaken well in advance to ensure preparedness activities such as stockpiling, capacity building, planning and assessment effectively so as to withstand future hazards and disasters (UNISDR, 2004). A well-prepared community, family and individuals are those who have easy access to early warning, knowledge and training on various pertinent subject on disasters management and such type of communities will have better protection measures (Dynes 2006; FEMA 2010). Disaster preparedness speaks about set of activities planned and implemented well in advance to check and combat severity of upcoming disasters, for example, preserving essential food commodities for all, clothes, first aid box, medicines for sick, keep ready 
with emergency shelters, assessing people, places and things at risk, organize capacity building training and information sharing on safety procedure.

A resilient community is envisaged with a high degree of social capital (Pelling, 2003) and is able to survive, respond to and recover from an extreme event. In Philippines, for example, community-based organizations have designed early warning systems, evacuation plans and provided community awareness campaigns. Before Hurricane Katrina, the Mary Queen of Vietnam Catholic Church in New Orleans East had developed its own evacuation plans knowing that a large portion of the population was senior citizens and other vulnerable groups.

In Australia, the Exmouth community are accustomed to prepare for probable cyclone, and whenever there is an early warning, people quickly without any delay get ready and do all things required. As a cyclone-prone community, each and every new comer to the community is introduced on the risks of their environment through their neighbours and various community groups. Households, which are part of the local networks of Exmouth, are encouraged to keep all the assets and properties in safer places usually kept outside; the moment official warning on cyclone is disseminated.

The Orang Asli indigenous tribe in Malaysia faced two big floods in 2013 and 2014. The floods occurred in these years were worst in these areas. As part of preparedness measures, the government of Malaysia has established flood relief centres, which is known as the Balairaya in their local language. Immediately after early warning receives from the concern department, the most vulnerable people move to the Balairaya and protect themselves from possible hazards and disasters. Most of the Orang Asli families are aware of the existence of JAKOA (Department of Orang Asli Development) under the Ministry of Rural and Regional Development; Malaysia is dealing with improving the standard of living through increasing their income, infrastructure facilities, social amenities and empowerment of the Orang Asli people as part of preparedness measures.

\section{Limitations in social capital}

Social capital can be valuable when social networks facilitate to strive for mutual benefit, norms, values of reciprocity (Putnam, 2000: 21). Social network expects both individuals and organizations work together to mobilize joint resources to achieve common goal of trustworthiness and being tolerant to each other's needs and differences in diversity. For example, every member in Women Self Help Group saves some amount of money into a common pool every month and whenever a woman needs some money to mitigate her needs and return back to a group as per the term and condition. However, this kind of practices will not work when there is lack of trust and understanding between and among the members (Portes, 1998:
13). The members in a Self Help Groups benefit as group give easy access to finance without imposing any kind of strict and long procedure and high rate of interest.

On the other hand, social capital can be harmful when it brings benefit to its group members but disallow outsiders to get access to resources (Portes 1998:16). For example, a community with same ethnic and socio-economic profile exclude others from using their resources. If these kinds of practices are not resolved, there may be conflict and break in the bond of unity and cooperation. Another negative aspect of social capital is when social networks squeeze individual freedom or importance, Berger, in his book 'Pyramids of Sacrifice' gives an example of how a woman from Mexican village felt confused between two choices, i.e. whether to continue her study and get better job, or send money to her relatives. This kind of strict rules and norms curtails an individual's freedom (Berger, 1974:217-224). Finally, social capital has also another negative effect when a group of community members prefer to live in exclusive areas and declined to be in contact with people from outside. The bond between and among the same ethnic groups is positive and beneficial, but the bond between and among the two different ethnic and cultural groups is not allowed become negative aspect of social capital. Social capital instead of bridging the gap between the two worlds (rich and poor) widens the gap among the two different communities. Social capital restricts individual freedom and gives importance to only groups (Portes and Landolt 1996). Individuals undertaking any social enterprise need to obey certain rules, norms and does and don't and an individual not allowed to develop his norms or practices. The group does not entertain personal development; neither allows any innovative thought and ideas to explore. In such a scenario, it gives a sense as if it were creating unwanted results (Portes and Landolt 1996).

\section{Discussion}

From the time immemorial, many countries and regions invest enormous amount of resource in relief, response and rehabilitation program and least is invested on pre-disaster intervention. Individuals, groups and communities can better respond to hazards and disasters when they are acquired with pertinent skills, techniques and know-how. Therefore, conscious efforts need to be given by the government, international non-government organizations and grass root level civil society organizations to invest resources on enhancing capacities in all aspect of life so as to reduce vulnerabilities of people, places and infrastructures.

The post-disasters response and recoveries in many countries clearly indicate that the relatives, neighbours and friends with the network of social relationship and collective action and cooperation rescue, evacuate, feed the hungry and 
shelter the homeless immediately after disasters. Therefore, the responsible administrations and other secondary stakeholders must recognize the contribution of social capital in day today affairs and promote user groups and nurture them to take care the hopeless and hapless in the communities in normal and in disaster situation.

Social relations, trust and solidarity and interpersonal relation are gradually declining due to individualistic life in this modern world as a result of which more and more cases of social isolation and loneliness emerge and sooner or later people find no meaning in life and commit suicide. Therefore, everyone needs to realize the importance of social relation, networking building, collective action and cooperation so that peace, harmony and brotherhood may be materialized in the communities.

The social scientist and the author of social capital Tristan Clardge take the African and says "If you want to go fast, go alone. If you want to go far, go together". Going alone is exciting for some time, but in long run he or she gets worn out. In disaster situation, a single volunteer with charged energy cannot do all the work, rather group of people with coordinated efforts can achieve good results. Therefore, all efforts need to put in to make people united.

\section{Conclusion}

In and through the above evidence, the authors, researchers and scholars conclude that social is one of the very important living instruments to make disaster risk management effective and user-friendly. Individuals, groups and communities are solaced and empathized from social capital in times of emergency situation. This review paper focuses on understanding that social capital plays pivotal role both in risk management (i.e. managing pre-disaster situation) and in crisis management (i.e. managing crisis situation during and after disasters). In all these systematic phases of disaster risk management, i.e. response, recovery, prevention, mitigation and preparedness, social capital is invaluable
Fig. 1 Role of social capital in disaster management from empirical evidence at a glance

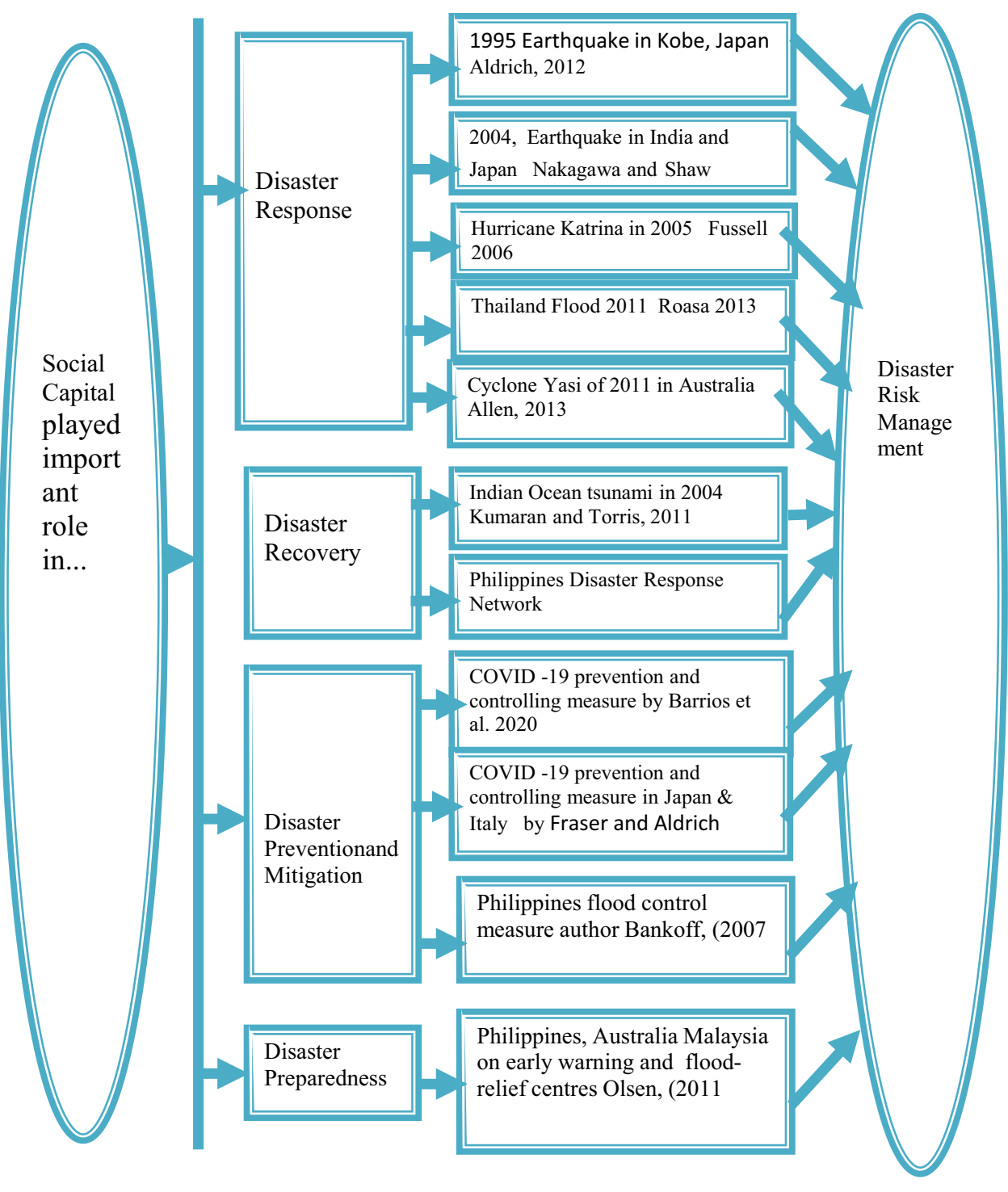


driver for reducing risk of hazards and vulnerabilities and plays a contributory role in enhancing capacities of people. It strives hard in normal and in crisis situation to prepare for, respond to and recover from adverse impact of disaster timely and successfully when government becomes indifferent providing psychological and emotional support to those who are fully down losing their dear ones in disasters.

Different types of social capital overlapped at times in action, but among the three types of social capital, bonding social capital was especially relevant in day-to-day activities like search, rescue and evacuation, supply of food, drinking water and first aid services to the people affected by disasters. The beneficial of bonding social capital was truly for lower-income groups. Through evidence, the strength of bonding social capital was seen in facilitating and mobilizing different resources to survive from the adverse impact of disasters and above all bonding social capital was observed rendering psychological support which in long run help people building resilience to hazard and disaster. The effective disaster risk management demands proper planning and implementation in and through public private partnership wherein government being enormous resource institution must play a greater role engaging and capacitating communities and non-government organizations at large to be a real help of victims during and after disasters.

Although the focus of this paper has been on social capital in the context of disaster risk management, the operational mechanism of social capital needs to be critically looked into in order to create healthy and harmonious groups and communities. Social capital needs to appreciate rather than depreciate for use. Despite all strength in abundance, social capital in the form of bonding, bridging and linking capital at times plays like a double-edge sword which likes to embrace group and disown other one and this kind of practices and feeling in the groups, networks and communities may be harmful in responding to disasters effectively (Figs. 1 and 2).

\begin{tabular}{|l|}
\hline Bonding: socio- \\
psychological support, \\
financial and livelihood \\
support for recovery \\
Bridging: Information sharing \\
on rehabilitation support, \\
information on job \\
opportunity \\
Linking: Short and long term \\
rehabilitation and \\
development work
\end{tabular}

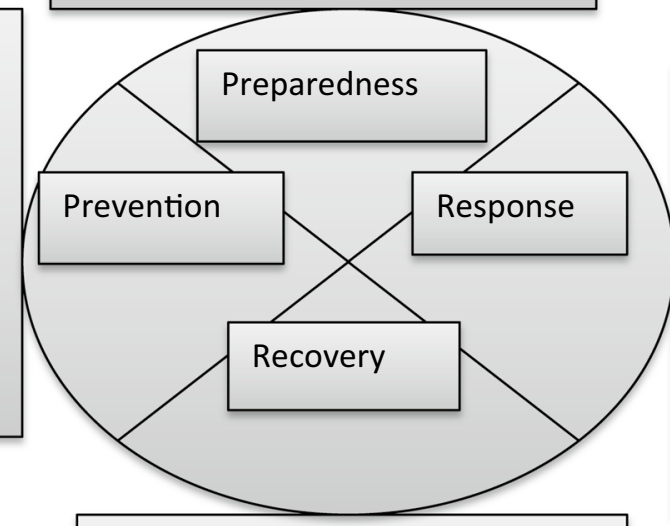

Bonding: Search, rescue, evacuation of the most vulnerable in pre, during and after disaster situation. Provide food, water and shelter.

Bridging: Information sharing on relief program, NGOs provide relief materials

Linking: Govt. provide relief like food and non-food items, shelters the most affected people
Bonding: Search, rescue, evacuation of the most vulnerable in pre, during and after disaster situation. Bridging: NGOs and volunteers support in risk and crisis management program Linking: Evacuation measures by external rescue officers

Fig. 2 Role of bonding, bridging and linking social capital in disaster management cycle (compiled referring to the empirical evidences from across the many countries) 
Acknowledgements The literature review paper titled Role of Social Capital in Disaster Risk Management: A theoretical Perspective in special reference to the district of Puri, Odisha state, India, is part of my $\mathrm{PhD}$ research work prepared with the guidance and direct supervision of my guide Dr. Supriya Pattanayak, Vice Chancellor, Centurion University of Technology and Management, Bhubaneswar. I deeply express my gratitude to my guide for her invaluable insight and guidance in bringing out this piece of review paper. I also thank the librarian, CUTM and my colleagues for extending me necessary help and support. This paper has not been supported by any external funding partners. This is purely a desk review of literature of the disasters studies across many countries published in eminent journals.

\section{References}

Adler PS, Kwon SW (2014) Social capital maturation of a field of research. Acad Manag Rev 39(4):412-422

Aldrich D (2012a) Social, not physical, infrastructure: the critical role of civil society in disaster recovery. Disasters: The Journal of Disaster Studies. Policy Manage 36:398-419

Aldrich DP (2012b) Building resilience: social capital in post-disaster recovery. University of Chicago Press, Chicago

Aldrich D (2012c) Building Resilience: Social Capital in Post-disaster Recovery. The University of Chicago Press, Chicago

Aldrich D, Meyer M (2015) Social capital and community resilience. Am Behav Sci 1-16

Allen M (2013) Deconstructing 'Resilience' in the aftermath of disasters in Australia, The Senshu Soc Capital Rev 4

Berger PL (1974) A tale of two moralities. In: Pyramids of Sacrifice, Peter L Berger, Allen lane, London

Bai JJ, Jin W, Wan C (2020) The impact of social capital on individual responses to COVID-19 Pandemic: evidence from social distancing." SSRN paper. https://papers.ssrn.com/sol3/papers.cfm?abstr act_id $=3609001$

Barrios JM, Benmelech E, Hochberg YV, Sapienza P, Zingales L (2020) Civic capital and social distancing during the Covid-19 Pandemic (No. w27320). National Bureau of Economic Research. https://www.nber.org/papers/w27320

Blair RA, Morse BS, Tsai LL (2017) Public health and public trust: Survey evidence from the Ebola Virus Disease epidemic in Liberia. Soc Sci Med 172:89-97

Borgonovi F, Andrieu E (2020) Bowling together by bowling alone: social capital and covid-19. Covid Economics 17:73-96

Bartscher AK, Seitz S, Slotwinski M, Siegloch S, Wehrhofer N (2020) € Social Capital and the Spread of Covid-19: Insights from European Countries. https://www.iza.org/publications/dp/13310/social-capit al-and-the-spread-ofcovid-19-insights-from-european-countries

Berkes F, Ross H (2013) Community resilience: Toward an integrated approach. Soc Nat Resour 26(1):5-20

Bourdieu P (1986) Forms of Social Capital. In: Richardson J (ed) Handbook of theory and research for the sociology of education. Greenwood Press, Westport CT, pp 241-260

Bankoff G (2007) Dangers to going it alone: social capital and the origins of community resilience in the Philippines. Contin Chang 22(2):327-355

Committee on Disaster Research in the Social Sciences and National Research Council. (2006) Facing Hazards and Disasters: Understanding human dimensions. Washington D.C.: National Academic Press.

Coleman JS (1988) Social capital in the creation of human capital. American Journal of Sociology (Special Issue on Organizations and Institutions: Sociological and Economic Approaches to the Analysis of Social Structure), S95-S120.

Coleman JS (1990) Foundations of Social Theory. Cambridge, MA: Harvard University Press. CPN (Civic Practices Network) (1997). 'Social capital', at http://www.cpn.org/sections/tools/ models/socialcapital.html

Cardona OD (2004) The Need for Rethinking the Concepts of Vulnerability and Risk from a Holistic Perspective: A necessary review and criticism for effective risk management. In G. Bankoff, G. Frerks, and D. Hilhorst (Eds.), Mapping

Dynes RR (2006) Social capital: dealing with community emergencies. Homeland Security Affairs 2(2):1-26

Dynes R (2005) Community Social Capital as the Primary Basis of Resilience. University of Delaware Disaster Research Center Preliminary Paper \#344.

Domínguez S, Watkins C (2003) Creating networks for survival and mobility: Social capital among African-American and LatinAmerican low-income mothers. Soc Probl 50(1):111-135

Delica-Willson Z, Wilson R (2004) Vulnerability Reduction: A tasks for the vulnerable themselves. In: Bankoff G, Frerks G, Hilhorst D (eds) Mapping Vulnerability: Disaster, development and people (pp.145-158). London, UK: Earthscan

Dynes R (2002) The Importance of Social Capital in Disaster Response, Disaster Reseach Center Paper, University of Delaware

Edgington WD (2010) Reconstructing Kobe: The geography of crisis and opportunity. UBC Press, Vancouver

FEMA (Federal Emergency Management Agency). (2010) Developing and maintaining emergency operation plans. Washington DC: Federal Emergency Management Agency.

Fraser T, Aldrich DP (2020) Social Ties, Mobility, and COVID-19 spread in Japan. https://papers.ssrn.com/sol3/papers.cfm?abstr act_id=3544373

Fukuyama F (1995) Trust: The social virtues and the creation of prosperity. The Free Press, New York

Guha-Sapir D, Hoyois Ph, Below R (2016) Annual disaster statistical review 2016: The numbers and trends. CRED, Brussels

Guha-Sapir D, Vos F, Below R, Ponserre S (2011) Annual Disaster Statistical Review 2010: The numbers and trends. [Accessed: 5 June 2012], retrieved from: http://www.cred.be/sites/default/ files/ADSR_2010.pdf

Granovetter M (1983) The strength of weak ties: a network theory revisited, Sociol. Theory 201-233

Hanifan LJ (1916) The Rural School Community Center. Annals of the American Academy of Political and Social Science, 67(New Possibilities in Education), 130-138. Available From: https:// doi.org/10.1177/000271621606700118.

Huvila I, Ek S, Widén G (2014) Information sharing and the dimensions of social capital in second life. J Inf Sci 40(2):237-248

IFRCRCS (2005) World Disaster Report 2005: Focus on information. In: Disasters. Geneva: International Federation of Red Cross and Red Crescent Societies

James H (2012) Social capital, resilience and transformation among vulnerable groups in the Burmese delta after Cyclone Nargis. ARC Discovery Project on "demographic Consequences of Asian Disasters: Family Dynamics, Social Ca- pital and Migration Patterns' (p. na). na: The Australian National University

Koh C (2008) Disaster Preparedness and Social Capital

Keeley B (2007) Human capital: How what you know shapes your life. http://lst-iiep.iiep-unesco.org/cgi

Kates RW, Pijawka D (1977) From Rubble to Monument: the pace of reconstruction. In: Haas JE, Kates RW, Bowden MJ (eds) Reconstruction Following Disaster. MIT Press, Cambridge, pp 1-23

Kumaran M, Torris T (2011) The Role of NGOs in the Tsunami Relief and Reconstruction in Cuddalore South India. In: Karan PP, Subbiah SP (eds) The Indian Ocean Tsunami: The global response to 
a natural disaster. The University Press of Kentucky, Lexington, pp 183-212

Kokubun K (2020) Social capital may mediate the relationship between social Distance and COVID-19 Prevalence. ArXiv preprint arXiv: 2007.09939

Kaniasty K, Norris FH (1993) A test of the social support deterioration model in the context of natural disaster. J Pers Soc Psychol 64(3):395-408

Lin N (2008) A Network Theory of Social Capital. In: Castiglione D, van Deth JW, Wolleb G (eds) The handbook of social capital. Oxford University Press, New York, pp 50-69

Montz BE, Tobin GA, Hagelman RR (2017) Natural hazards: Explanation and integration. Guilford Publications, New York

Mayunga JS (2007) Understanding and applying the concept of community disaster resilience: a capital-based approach. Landscape Archi. https://doi.org/10.1146/annurev.energy.32.051807.090348

Mitchell A, Glavovic B, Hutchinson B, MacDonald G, Roberts M, Goodland J (2010) Community-based civil defence emergency management planning in Northland, New Zealand. Australasian Journal of Disaster and Trauma Studies, (1), retrieved from: http:// www.massey.ac.nz/ trauma/issues/2010-1/mitchell.htm

Nakagawa Y, Shaw R (2004) Social capital: a missing link to disaster recovery. Int J Mass Emerg Disasters 22(1):5-34

Norris FH, Friedman MJ, Watson PJ, Byrne CM, Diaz E, Kaniasty K (2002) "60,000 Disaster Victims Speak: Part I. An Empirical Review of the Empirical Literature, 1981- 2001. Psychiatry Interpersonal Biol Process 65(3): 207-239

Oliver-Smith A (1999) "What is a Disaster?": Anthropological perspectives on a persistent question. In: Oliver-Smith S, Hoffman $S$ (eds) The Angry Earth: Disaster in anthropological perspective. Routledge, New York

O'Keefe P, Westgate K, Wisner B (1976) Taking the Naturalness out of Natural Disasters. Nature 260:566-567

OECD (2001) The Wellbeing of nations: The role of human and social capital, education and skills. Paris, France: OECD Centre for Educational Research and Innovation

Pfefferbaum B, Richard L, Horn V, Rose L, Pfefferbaum, (2017) A conceptual framework to enhance community resilience using social capital. Clin Soc Work J 45(2):102-110. https://doi.org/10.1007/ s10615-015-0556-z

Poortinga W (2012) Community resilience and health: The role of bonding, bridging, and linking aspects of social capital. Health Place 18:286-295

Putnam R (1993) Making democracy work: Civic traditions in modern italy. Princeton University Press, Princeton

Putnam R (1995) 'Bowling alone: America's declining social capital', Journal of Democracy, 6(1), 65 \pm 78

Perry RW (1979) Evacuation Decision-making in Natural Disasters. Mass Emergency 4(1):25-38

Poteyeva M, Denver M, Barsky LE, Aguirre BE (2007) Search and Rescue Activities in Disasters. In: Rodríguez H, Quarantelli EL, Dynes RR (eds) Handbook of Disaster Research. Springer, New York, pp 200-216

Patterson O, Weil F, Patel K (2010) The role of community in disaster response: conceptual models. Popul Res Policy Rev 29(2):127-141
Pelling M (2003) The Vulnerability of Cities: Natural disasters and social resilience. Sterling: Earthscan

Putnam RD (2000) Bowling alone: The collapse and revival of American community. Simon \& Schuster, New York

Portes A (1998) 'Social capital :its origins and applications in modern sociology'. Ann Rev Sociol 24:1-24

Portes A, Landolt P (1996) The downside of social capital. Am Prospect. 1996; 26(May-June):18-22

Ritchie LA, Gill DA (2007) Social capital theory as an integrating theoretical framework in technological disaster research. Sociol Spectr 27(1):103-129

Roasa D (2013) The DIY Disaster plan: How informal Networks Battled Bangkok's Worst Flood. The Rockefeller Foundation Informal City Dialogues Vol 1.

Szreter S, Woolcock M (2004) Health by association? Social Capital, Social theory and the political economy of public health. Int $\mathbf{J}$ Epidemiol 33(4):650-667

Siegler V (2014) Measuring Social Capital. Office for National Statistics

Sobel J (2002) Can we trust social capital? J Economic Literature 40(1):139-154

Sanyal S, Routray JK (2016b) "Social Capital for Disaster Risk Reduction and Management with Empirical Evidences from Sundarbans of India. Int J Disaster Risk Reduct 19:101-111

Smith K, Petley DN (2009) Environmental Hazards: Assessing risk and reducing disaster, 5th edn. Routledge, London

Tobin-Gurley J, Peek L, Loomis J (2010) Displaced single mothers in the aftermath of hurricane Katrina: Resource needs and resource acquisition. Int J Mass Emerg Disasters 28(2):170-206

UNSFDRR, Sendai Framework for Disaster Risk Reduction, United Nations Office for Disaster Risk Reduction, 2015 - 2030

UN/ISDR (2005) "Hyogo Framework for Action 2005-2015: Building the Resilience of Nations and Communities to Disasters". World Conference on Disaster Reduction, pp.18-2 January 2005, Kobe Hyogo, Japan Reduction Education, www.Oecd.org/daf/fin/catrisks

UN/ISDR \& UN/OCHA, (2008) Disaster preparedness for effective response guidance and indicator package for implementing priority five of the Hyogo framework. United Nations secretariat of the International Strategy for Disaster Reduction (UN/ISDR) and the United Nations Office for Coordination of Humanitarian Affairs (UN/OCHA), Geneva, Switzerland.

UNISDR (2004) Terminology: Basic terms of disaster risk reduction. The UNISDR Secretariat. Available at http://www.unisdr.org/files/ 7817_7819isdrterminology11.pdf

UNDP. (2016b) Social Capital: The Invisible Face of Resilience.

Varda DM, Forgette R, Banks D, Contractor N (2009) Social network methodology in the study of disasters: Issues and insights prompted by post-Katrina research. Popul Res Policy Rev 28(1):11-29

Woolcock M (1998) Social capital and economic development: Toward a theoretical synthesis and policy framework. Theory Soc 27(2):151-208

Zhao Y (2013) Social networks and reduction of risk in disasters: an example of the Wenchuan earthquake. In: Yeung W-JJ, Yap MT (eds) Economic stress, human capital, and families in Asia. Springer, Berlin, pp 171-182 